\title{
Effect of oral acyclovir against primary and secondary viraemia in incubation period of varicella
}

\author{
S Suga, T Yoshikawa, T Ozaki, Y Asano
}

\begin{abstract}
The effect of oral acyclovir (approximately $40 \mathrm{mg} / \mathrm{kg}$ daily in four divided doses) against primary and secondary viraemia of varicella zoster virus (VZV) was examined in 27 children susceptible to VZV who were exposed to the virus in their families and their clinical features were compared with those of 19 nontreated subjects. The infection was confirmed by a fluorescent antibody to membrane antigen assay in $11(85 \%)$ of 13 children who received acyclovir for the first seven days after exposure to VZV and in $11(79 \%)$ of 14 who received acyclovir for the next seven days. The geometric mean antibody titre of the former group was significantly higher than that of the latter group. Varicella developed in 10 $(91 \%)$ and was subclinical in one $(9 \%)$ in the former group, whereas a very mild disease occurred in three $(27 \%)$ and was subclinical in eight $(73 \%)$ in the latter group. The severity of varicella was significantly greater in the former group than that in the latter group. On the other hand, all of the control group developed typical varicella and their clinical features were more severe than those of the acyclovir administered group. These data indicate that oral acyclovir more effectively inhibits replication of $V Z V$ in secondary viraemia than that of the primary viraemia.

(Arch Dis Child 1993; 69: 639-643)
\end{abstract}

Varicella is a common contagious disease of childhood that is caused by primary infection with varicella zoster virus (VZV). It is usually a benign and self limited disease in normal children, but the disease is generally severe in susceptible newborn infants, immunocompromised children, and adults. ${ }^{1}$ It is also well known that secondary cases in households are more severe than primary cases. ${ }^{2}$ Although the pathogenesis of varicella is not well understood because of the lack of susceptible experimental animals ${ }^{3}$ and the fastidious nature of VZV in the laboratory, ${ }^{4}$ the disease is believed to follow dual VZV viraemia. ${ }^{5}$ Secondary viraemia has been demonstrated between five days before and one day after clinical onset of disease, ${ }^{6-8}$ however, the presence of primary viraemia is still speculative. Balfour et al and Dunkle et al have reported that acyclovir is a safe treatment which reduces the duration and severity of varicella in normal children when it is initiated during the first 24 hours of the rash. ${ }^{9}{ }^{10}$ Recently, we found that varicella can be prevented or modified by administration of oral acyclovir late in the incubation period of the disease. ${ }^{11}$ In the present study, we compared the effect of oral acyclovir against primary and secondary viraemia during the incubation period of varicella.

\section{Patients and Methods}

\section{STUDY POPULATION}

Between March and June 1992, 27 children who had no history of varicella and had been exposed to a sibling with varicella were enrolled in this study. The subjects were separated in two groups (first and second groups) and received acyclovir (30-80 mg/kg daily in four divided doses) orally for seven days during the incubation period of varicella. The first day of exposure to a sibling with varicella was assigned as day 0 . The first group consisted of 13 children (seven boys and six girls) with a mean age of $2 \cdot 1$ years (range from 0.6 months -5 years), who received acyclovir (mean $44 \mathrm{mg} / \mathrm{kg}$, range from $35-80 \mathrm{mg} / \mathrm{kg}$ ) starting between day 0 and day 3 (mean day $1 \cdot 4)$. The second group consisted of 14 children (nine boys and five girls) with a mean age of 2.9 years (range from $0.5-9$ years), who received acyclovir (mean $49 \mathrm{mg} / \mathrm{kg}$, range from $30-80 \mathrm{mg} / \mathrm{kg}$ ) starting between day 6 and day 10 (mean day 8.5). Their clinical features were compared with those of 19 age matched subjects (seven boys and 12 girls) with a mean age of 2.9 years (range from $0.3-8$ years), who were exposed to the virus in their families but did not receive acyclovir. A complete medical history and physical examination was obtained by authors. Informed consent was obtained from parents of the subjects enrolled in this study after the project was thoroughly explained. Children with a history of immune deficiency, those taking cytotoxic or immunosuppressive drugs, those who had received immunoglobulin within the past four weeks, and those who had been vaccinated against VZV were excluded from participation.

EVALUATION OF SEVERITY OF VARICELLA

The presumed day of varicella onset was assigned as 14 days after exposure to a sibling with varicella. Clinical evaluations were performed on approximately day 14 (acute phase) and on day 28 to day 42 (convalescent phase), respectively. If varicella exanthem appeared, the number of lesions was counted 
Table 1 Clinical findings and antibody response to VZV in 13 family contacts of varicella who were treated with oral acyclovir during the first seven days of the incubation period

\begin{tabular}{|c|c|c|c|c|c|c|c|c|c|c|}
\hline \multirow[b]{3}{*}{$\begin{array}{l}\text { Family } \\
\text { No }\end{array}$} & \multirow[b]{3}{*}{$\begin{array}{l}\text { Case } \\
\text { No }\end{array}$} & \multirow[b]{3}{*}{$\begin{array}{l}\text { Age } \\
\text { (years) }\end{array}$} & \multirow[b]{3}{*}{ Sex } & \multirow{3}{*}{$\begin{array}{l}\text { Interval between } \\
\text { exposure and } \\
\text { administration } \\
\text { of acyclovir } \\
\text { (days) }\end{array}$} & \multirow{3}{*}{$\begin{array}{l}\text { Dose of } \\
\text { acyclovir } \\
\text { (mg/kg/day) }\end{array}$} & \multicolumn{3}{|l|}{ Skin rash* } & \multirow{2}{*}{\multicolumn{2}{|c|}{$\begin{array}{l}\text { Antibody titres } \\
(F A M A) \dagger\end{array}$}} \\
\hline & & & & & & \multirow[b]{2}{*}{ Development } & \multirow{2}{*}{$\begin{array}{l}\text { Days after } \\
\text { onset of } \\
\text { index case }\end{array}$} & \multirow{2}{*}{$\begin{array}{l}\text { No of } \\
\text { skin } \\
\text { lesions }\end{array}$} & & \\
\hline & & & & & & & & & Acute & Convalescent \\
\hline \multirow[t]{2}{*}{1} & Index & 5 & M & & & Yes & & & - & - \\
\hline & 1 & 2 & M & 0 & 42 & Yes & 18 & 128 & $<4$ & $>128$ \\
\hline \multirow[t]{2}{*}{2} & Index & 0.9 & $\mathbf{M}$ & & & Yes & & & - & - \\
\hline & 2 & 3 & $F$ & 1 & 40 & Yes & 17 & 135 & $<4$ & 128 \\
\hline \multirow[t]{2}{*}{3} & Index & 3 & $\mathbf{M}$ & & & Yes & & & - & - \\
\hline & 3 & $0 \cdot 8$ & $\mathbf{M}$ & 1 & 47 & Yes & 18 & 100 & $<4$ & 64 \\
\hline \multirow[t]{2}{*}{4} & Index & 1 & M & & & Yes & & & - & - \\
\hline & 4 & 4 & $\mathrm{~F}$ & 1 & 36 & Yes & 17 & 105 & $<4$ & 128 \\
\hline \multirow[t]{2}{*}{5} & Index & 4 & $\mathrm{~F}$ & & & Yes & & & - & - \\
\hline & 5 & 2 & $\mathrm{~F}$ & 2 & 43 & Yes & 17 & 60 & $<4$ & 128 \\
\hline \multirow[t]{2}{*}{6} & Index & 5 & $\mathrm{~F}$ & & & Yes & & & - & - \\
\hline & 6 & 2 & $\mathbf{M}$ & 2 & 43 & Yes & 19 & 510 & $<4$ & $>128$ \\
\hline \multirow[t]{2}{*}{7} & Index & 3 & M & & & Yes & & & - & - \\
\hline & 7 & 5 & $\mathrm{~F}$ & 1 & 38 & Yes & 17 & 190 & $<4$ & $>128$ \\
\hline \multirow[t]{2}{*}{8} & Index & 3 & $\mathbf{M}$ & & & Yes & & & - & - \\
\hline & 8 & 2 & M & 1 & 36 & Yes & 17 & 108 & $<4$ & $>128$ \\
\hline \multirow[t]{2}{*}{9} & Index & 3 & M & & & Yes & & & - & - \\
\hline & 9 & 1 & M & 2 & 40 & Yes & 16 & 51 & $<4$ & 64 \\
\hline \multirow[t]{2}{*}{10} & Index & 4 & $\mathrm{~F}$ & & & Yes & & & - & - \\
\hline & & 2 & $\mathrm{~F}$ & 3 & 80 & Yes & 24 & 15 & $<4$ & 128 \\
\hline \multirow[t]{2}{*}{11} & Index & 6 & $\mathbf{M}$ & & & Yes & & & - & - \\
\hline & 11 & 2 & $F$ & 1 & 46 & No & & & $<4$ & 16 \\
\hline \multirow[t]{2}{*}{12} & Index & 3 & $\mathbf{F}$ & & & Yes & & & - & - \\
\hline & 12 & $0 \cdot 7$ & $\mathbf{M}$ & 2 & 43 & No & & & $<4$ & 4 \\
\hline \multirow[t]{2}{*}{13} & Index & 4 & $\mathrm{~F}$ & & & Yes & & & - & - \\
\hline & 13 & $0 \cdot 6$ & $M$ & 1 & 35 & No & & & $<4$ & $<4$ \\
\hline
\end{tabular}

ॠThe first day of onset of skin rash in index cases was considered to be the first day of exposure in their siblings.

tAcute: approximately 14 days after onset of index cases; convalescent: $28-42$ days after onset of index cases.

daily on the entire body surface except in the area of the scalp. The parents recorded body temperature of their children every eight hours after onset of varicella. Serum samples were obtained on acute and convalescent phases and frozen at $-20^{\circ} \mathrm{C}$ for the assessment of $\mathrm{VZV}$ antibodies.

\section{SEROLOGICAL TESTS}

Antibody titres to VZV were determined by the standard fluorescent antibody to membrane antigen (FAMA) test. ${ }^{12}$ FAMA titres were expressed as reciprocals of serum dilutions. A serological diagnosis of varicella was defined as a fourfold or greater rise in FAMA titres between paired acute and convalescent sera. Subclinical VZV infection was defined as seroconversion occurring without any associated vesicular exanthem compatible with varicella.

\section{STATISTICS}

For comparison of both groups, the $\chi^{2}$ test, Wilcoxon rank sum test, and Students $t$ test were employed.

\section{Results}

Clinical findings and antibody responses to VZV of the first and second groups are shown in tables 1 and 2 . Among the first group, one child received acyclovir at the onset of the index case, seven on the next day, four on the third day, and one on the fourth day, respectively. Eleven $(85 \%)$ of 13 children became seropositive by FAMA test 28 days to 42 days after exposure. Ten of the 11 exhibited clinical varicella 16 to 24 days after exposure. One child (case 6 in table 1) showed typical symptoms such as more than $\mathbf{5 0 0}$ skin lesions and high temperature for four days, whereas nine children had mild to moderate clinical features, characterised by a lack of fever, reduced number of skin lesions (mean 140). Another child (case 11 in table 1) had subclinical VZV infection.

Among the second group, three children received acyclovir on day 7 , one on day 8 , nine on day 9 , and one on day 10 after exposure, respectively. Eleven $(79 \%)$ of the 14 became seropositive 28 days to 42 days after the exposure. Three children developed a very mild form (mean three skin lesions) of the disease without fever 14 to 16 days after the exposure. The other eight children had subclinical VZV infection.

All 19 children of the control group developed moderate to severe varicella and there was an increased temperature in $11(58 \%)$.

Table 3 compares seroconversion rates and severity of clinical features between the three groups. Seroconversion rate was not significantly different between the first and second groups. However, the rate of clinical infection was significantly lower in the second group than those of the first and control groups $(p<0.01)$. The extent of the skin rash in the first group was greater than that in the second group $(p<0.05)$. The frequency of fever in both groups was significantly lower than that of the control group $(p<0.01)$. The extent of the skin rash of the first group was less than that of the control group, but not statistically significant. The level of FAMA titres in 22 family contacts who were infected with VZV was compared between the first and second groups. The first group had a significantly higher level of the antibody titres than that of the second group in the convalescent phase (geometric mean (SD) antibody titres $\left(\log _{10}\right)$ were $2.0 \quad(0.3)$ v $1.4 \quad(0.4)$; $\mathrm{p}<0 \cdot 01$ ). 
Table 2 Clinical findings and antibody response to VZV in 14 family contacts of varicella who were treated with oral acyclovir during the next seven days of the incubation period

\begin{tabular}{|c|c|c|c|c|c|c|c|c|c|c|}
\hline \multirow{3}{*}{$\begin{array}{l}\text { Family } \\
\text { No }\end{array}$} & \multirow{3}{*}{$\begin{array}{l}\text { Case } \\
\text { No }\end{array}$} & \multirow{3}{*}{$\begin{array}{l}\text { Age } \\
\text { (years) }\end{array}$} & \multirow[b]{3}{*}{ Sex } & \multirow{3}{*}{$\begin{array}{l}\text { Interval between } \\
\text { exposure and } \\
\text { administration } \\
\text { of acyclovir } \\
\text { (days) }\end{array}$} & \multirow{3}{*}{$\begin{array}{l}\text { Dose of } \\
\text { acyclovir } \\
\text { (mg/kg/day) }\end{array}$} & \multicolumn{3}{|l|}{ Skin rash ${ }^{\star}$} & \multirow{2}{*}{\multicolumn{2}{|c|}{$\begin{array}{l}\text { Antibody titres } \\
(F A M A) \dagger\end{array}$}} \\
\hline & & & & & & \multirow[b]{2}{*}{ Development } & \multirow{2}{*}{$\begin{array}{l}\text { Days after } \\
\text { onset of } \\
\text { index case }\end{array}$} & \multirow{2}{*}{$\begin{array}{l}\text { No of } \\
\text { skin } \\
\text { lesions }\end{array}$} & & \\
\hline & & & & & & & & & Acute & Convalescent \\
\hline 1 & Index & 4 & $\mathbf{M}$ & & & Yes & & & - & - \\
\hline \multirow{3}{*}{2} & 1 & 1 & $\mathbf{M}$ & 9 & 42 & Yes & 14 & 1 & $<4$ & 32 \\
\hline & Index & 3 & $\mathrm{~F}$ & & & Yes & & & - & - \\
\hline & 2 & 1 & $\mathrm{~F}$ & 9 & 80 & Yes & 16 & 3 & $<4$ & 64 \\
\hline 3 & $\underset{3}{\text { Index }}$ & $\begin{array}{l}3 \\
1\end{array}$ & $\begin{array}{l}\mathrm{M} \\
\mathrm{F}\end{array}$ & 8 & 80 & $\begin{array}{l}\text { Yes } \\
\text { Yes }\end{array}$ & 15 & 6 & $<\overline{4}$ & $12 \overline{8}$ \\
\hline \multirow[t]{2}{*}{4} & Index & 0.5 & $\mathbf{M}$ & 0 & & $\begin{array}{l}\text { Yes } \\
\text { Yes }\end{array}$ & 10 & 0 & $\begin{array}{r}<4 \\
-\end{array}$ & $\begin{array}{r}128 \\
-\end{array}$ \\
\hline & 4 & 4 & M & 9 & 30 & No & & & $<4$ & 16 \\
\hline \multirow[t]{2}{*}{5} & Index & 1 & M & & & Yes & & & - & - \\
\hline & 5 & 3 & $\mathbf{M}$ & 10 & 33 & No & & & $<4$ & 64 \\
\hline 6 & $\underset{6}{\text { Index }}$ & 4 & $M$ & & & Yes & & & - & - \\
\hline \multirow[t]{2}{*}{7} & $\begin{array}{l}0 \\
\text { Index }\end{array}$ & $\begin{array}{l}1 \\
0.4\end{array}$ & $\begin{array}{l}\mathbf{M} \\
\mathbf{M}\end{array}$ & 9 & 54 & $\begin{array}{l}\text { No } \\
\text { Yes }\end{array}$ & & & $<4$ & $\begin{array}{r}32 \\
-\end{array}$ \\
\hline & & 2 & $\mathrm{~F}$ & 9 & 44 & No & & & $<4$ & 8 \\
\hline \multirow[t]{2}{*}{8} & Index & 5 & $\mathbf{M}$ & & & Yes & & & - & - \\
\hline & 8 & 7 & M & 9 & 36 & No & & & $<4$ & 8 \\
\hline \multirow[t]{2}{*}{9} & Index & 0.5 & M & & & Yes & & & - & - \\
\hline & 9 & 0.5 & F & 9 & 40 & No & & & $<4$ & 8 \\
\hline \multirow[t]{2}{*}{10} & Index & 5 & F & & & Yes & & & - & - \\
\hline & 10 & 3 & $\mathbf{M}$ & 7 & 40 & No & & & $<4$ & 8 \\
\hline \multirow[t]{2}{*}{11} & Index & 7 & F & & & Yes & & & - & - \\
\hline & 11 & 9 & $\mathbf{M}$ & 6 & 80 & No & & & $<4$ & 32 \\
\hline \multirow[t]{2}{*}{12} & Index & 3 & F & & & Yes & & & - & - \\
\hline & 12 & 1 & M & 9 & 40 & No & & & $<4$ & $<4$ \\
\hline \multirow[t]{2}{*}{13} & Index & 6 & $\mathbf{M}$ & & & Yes & & & - & - \\
\hline & 13 & 0.5 & $\mathbf{F}$ & 9 & 46 & No & & & $<4$ & $<4$ \\
\hline \multirow[t]{2}{*}{14} & Index & 4 & F & & & Yes & & & - & - \\
\hline & 14 & 6 & $\mathbf{M}$ & 7 & 40 & No & & & $<4$ & $<4$ \\
\hline
\end{tabular}

^The first day of onset of skin rash in index cases was considered to be the first day of exposure in their siblings.

†Acute: approximately 14 days after onset of index cases; convalescent: $28-42$ days after onset of index cases.

\section{Discussion}

VZV is highly species specific and has been demonstrated to infect naturally only humans and great apes. ${ }^{13}$ As a consequence, much of what is understood about the pathophysiology of VZV infection has been deduced by analogy with studies of experimental infections with other herpesviruses, such as herpes simplex virus or pseudorabies virus. It is generally believed that the primary infection with VZV has four stages before exanthematous disease: invasion and replication at a local site, a low degree primary viraemia, replication in the internal organs, and a secondary viraemia with greater magnitude. ${ }^{5}$ Among those, secondary viraemia had been proved in immunologically normal children with varicella just before and after onset of disease. ${ }^{6-8}$

In this study, we administered acyclovir orally to household contacts in the first seven days or the next seven days of the incubation period of varicella. The results have clearly indicated that oral acyclovir with relatively low doses modifies the clinical course of the disease. However, the degree of modification was different between both groups. Clinical attack rate was $27 \%$ in the second group in contrast to $91 \%$ in the first group and clinical features were milder in the second group than in the first group, although the seroconversion rate was not significantly different between the groups. In addition, the second group had a significantly lower level of antibody titres in the convalescent phase than that of the first group. Although the clinical attack rate and the severity of the disease were greater in the first group than the second group, they were lower when compared with the untreated control group. In general, most susceptible children who are exposed to VZV in their families develop typical varicella and the secondary cases are usually more severe than index cases.
One of the large series indicated that the secondary attack rate was $87 \%$ and the average number of skin lesions was approximately $50 \%$ greater in secondary cases than in index cases. ${ }^{2}$

It is difficult to explain the reason why oral acyclovir more effectively modifies the clinical course of the second group than that of the first group. Acyclovir is converted by a virus induced enzyme, thymidine kinase, to its monophosphate derivative, subsequent diphosphorylation and triphosphorylation are catalysed by cellular enzymes, and the acyclovir triphosphate inhibits replication of the virus. The degree of induction of the viral thymidine kinase may be different during the first seven days and the next seven days of the incubation period. This may be further supported by the findings reported elsewhere in which cellular and VZV thymidine kinase activities evaluated by a sensitive enzyme assay simultaneously started to increase 3-5 days before the onset of the clinical symptoms of varicella. ${ }^{14}$ This may help to explain why oral acyclovir more effectively modifies the clinical course of the second group than that of the first group.

Table 3 Comparison of clinical manifestations in three groups

\begin{tabular}{clll}
\hline & $\begin{array}{l}\text { First } \\
\text { group } \\
(n=13)\end{array}$ & $\begin{array}{l}\text { Second } \\
\text { group } \\
(n=14)\end{array}$ & $\begin{array}{l}\text { Control } \\
\text { group } \\
(n=19)\end{array}$ \\
\hline $\begin{array}{l}\text { Seroconversion (\%) } \\
\text { Clinical infection (\%) } \\
\text { No of lesions }\end{array}$ & $11(85)$ & $11(79)$ & ND \\
$1-10$ & $10(91)$ & $3(27)$ & $19(100)$ \\
$11-50$ & 0 & 3 & 0 \\
$51-150$ & 1 & 0 & 3 \\
$151-500$ & 7 & 0 & 5 \\
$\geqslant 501$ & 1 & 0 & 8 \\
Temperature $\geqslant 38 \cdot 0^{\circ} \mathrm{C}(\%) \dagger$ & 1 & 0 & 3 \\
& $1(9)$ & 0 & $11(58)$ \\
\hline
\end{tabular}

ND: not done.

ND: not done. * Significantly different between the first group and the second
group (clinical infection $p<0 \cdot 01$; number of lesions $\mathrm{p}<0.05$ ). TTe first and second groups had significantly lower incidence of fever than the control group $(p<0 \cdot 01)$. 
The question remains as to whether a higher dose of acyclovir more effectively prevents or modifies the clinical course of the disease in the first group than that observed in the present study.

1 Gershon AA, LaRussa P. Varicella-zoster virus infections In: Krugman S, Katz SL, Gershon AA, Wilfert CM, eds. Infectious diseases of children. 9th Ed. St Louis, Missouri: CV Mosby, 1992: 587-614.

2 Ross AH. Modification of chicken pox in family contacts by administration of gamma globulin. N Engl f Med 1962; 267: 369-76.

3 Asano Y, Albrecht P, Behr DE, Neff BJ, Vickers JH, Rastogi SC. Immunogenicity of wild and attenuated varicellazoster virus strains in rhesus monkeys. $\mathcal{f}$ Med Virol 1984; 14: 305-12.

4 Asano Y, Takahashi $M$. Studies of neutralization of varicella-zoster virus and serological follow-up of cases of varicella and zoster. Biken foumal 1978; 21: 15-23.

5 Grose C. Variation on a theme by Fenner: the pathogenesis of chickenpox. Pediatrics 1981; 68: 735-7.

6 Ozaki T, Ichikawa T, Matsui Y, et al. Viremic phase in nonimmunocompromised children with varicella. $f$ Pediat 1984; 104: 85-7.

7 Asano Y, Itakura N, Hiroishi Y, et al. Viremia is present in incubation period in nonimmunocompromised children with varicella. $\mathcal{f}$ Pediatr 1985; 106: 69-71.

8 Asano $\mathrm{Y}$, Itakura $\mathrm{N}$, Hiroishi Y, et al. Viral replication and immunologic responses in children naturally infected with immunologic responses in children naturally infected with varicella-zoster virus and in varic
f Infect Dis 1985; 152: 863-8.

9 Balfour HH, Kelly JM, Suarez CS, et al. Acyclovir treatment of varicella in otherwise healthy children. $\mathcal{F}$ Pediatr 1990 ; 116: 633-9.

10 Dunkle LM, Arvin AM, Whitley RJ, et al. A controlled trial of acyclovir for chickenpox in normal children. $N$ Engl $\mathcal{F}$ Med 1991; 325: 1539-44.

11 Asano Y, Toshikawa T, Suga S, et al. Post-exposure prophylaxis of varicella in family contact by oral acyclovir. phylaxis of varicella in family

12 Asano Y, Albrecht P, Vujcic LK, Quinnan GV Jr, Kawakami K, Takahashi M. Five-year follow-up study of recipients of live varicella vaccine using enhanced neutralization and fluorescent antibody membrane antigen assays. Pediatrics 1983; 72: 291-4.

13 Myers MG, Connelly BL. Animal models of varicella. f Infect Dis 1992; 166 (suppl 1): S48-50.

14 Kallander CFR, Gronowitz JS, Olding-Stenkvist E. Varicella zoster virus deoxythymidine kinase is present in serum before the onset of varicella. Scand $\mathcal{F}$ Infect Dis 1989; 21 : $255-7$.

\section{Commentary}

Varicella is common, with a 1992 general practitioner consultation rate $>600$ per 100000 population. Almost all infected children suffer at least a moderate constitutional illness, but the otherwise normal child will usually have no new lesions after four days and complications are rare. We must ask whether we want to interfere with varicella, an essentially benign illness in normal children. There is a growing pressure to intervene by administration of acyclovir within the first 24 hours of the rash. Balfour et al and Dunkle et al have shown in three recent publications that $2-18$ year olds so treated have less severe disease. ${ }^{1-3}$ Their results were statistically impressive but clinically unconvincing, for example 0.5 days less of new lesion formation. Certain patient groups might benefit more, for example the immunosuppressed, adolescents, children with chronic chest disease, and pregnant women. Children exposed to intrafamilial spread of varicella are also susceptible to more severe infection which may respond well to early acyclovir treatment. Varicella is most infectious in its prodrome and secondary cases in the family are not prevented when acyclovir is given to the index case.

The paper by Suga et al tries to answer the question whether oral acyclovir can minimise or even prevent secondary infection if given to susceptible family members during the incubation period? (But remember to keep asking, do we want to prevent infection in otherwise normal children?)

The small placebo controlled study targeted acyclovir treatment at either the first or second viraemic period. All of the control group developed moderate to severe varicella. The clinical severity and the attack rate $(91 \%$ in the first group, $27 \%$ in the second group) were reduced in both treatment groups. The data raise some important issues which are not discussed. The results are interpreted as showing seroconversion in 11 of 13 in the first group, and in 11 of 14 in the second group. Many would not accept an antibody rise from $<4$ to 8 (cases $7-10$ in the second group) as seroconversion, reducing the number with an antibody response in the second group to seven, only $50 \%$. Without acyclovir at least $85 \%-90 \%$ of susceptible household contacts will contract varicella from the index case. It may be desirable for these children to have a less severe illness (achieved in both treatment groups), but do we want $50 \%$ of them to remain susceptible to the virus later in childhood, perhaps even through to adolescence and adulthood when we know they can expect more severe disease? And how will we distinguish those who have had subclinical illness after acyclovir treatment from those who have had no illness at all? Only by serological tests on all children given acyclovir in the presumed incubation period who subsequently failed to show any clinical features of varicella. Realistically such follow up tests are unlikely to be achieved in busy general practice, resulting in potentially dangerous ignorance about the child's varicella status.

I am concerned about the efficacy of the antibody response, significantly greater in the first than the second group. Is it sufficient to prevent (a) reinfection and (b) early zoster? Information so far from children receiving acyclovir for varicella shows an adequate humoral and cellular response. However, the immune response to primary herpes simplex infection may be decreased after treatment with acyclovir, and some may suffer a more intense first herpetic recurrence. Might acyclovir given in the incubation period for varicella increase the problems of zoster? Suga et al seem to suggest in their discussion that we should find a higher dose to prevent more effectively clinical illness. Perhaps we should rather try to realise a dose that would allow mild clinical illness (we would know that the child had had varicella), and produce an effective and lasting antibody response, or simply treat the secondary family case promptly as recommended by Balfour et al and Dunkle et al.

Importantly, trials to date have shown acyclovir to be safe. The paper by Suga et al is another step in the study of the proper role of acyclovir in the treatment and prevention of varicella, but raises more questions than it answers. Further studies are awaited with interest. But if we want to prevent and/or minimise clinical varicella in high risk children (and normal children?), should we not concen- 